\title{
MEASUREMENT AND ANALYSIS OF TRANSMISSION LOSSES IN THE SUPPLY SYSTEM OF ELECTRIFIED TRANSPORT
}

\author{
Mikołaj Bartłomiejczyk ${ }^{1}$, Piotr Hołyszko², Piotr Filipek ${ }^{3}$ \\ 1 Gdańsk University of Technology, Faculty of Electrical and Control Engineering, Gdańsk, Poland, e-mail: \\ mikolaj.bartlomiejczyk@pg.gda.pl \\ 2 Municipal Transport Company in Lublin, Trolleybus Department, Lublin, Poland \\ ${ }^{3}$ Lublin University of Technology, Faculty of Electrical Engineering and Computer Science, Lublin, Poland, \\ e-mail: piotr.filipek@pollub.pl
}

Received: 2016.08.16

Accepted: 2016.09.26

Published: 2016.11.01

\begin{abstract}
The issue of electric energy saving in public transport is currently becoming a key area of interest, a fact connected with both an increase in society's environmental awareness and a rise in the prices of fuel and electricity. Electricity can be saved by reducing transmission losses in the supply system. The article presents a method of measurement and analysis of transmission losses in the supply system of electrified public transport on the example of trolleybus transport in Gdynia and Lublin in Poland.
\end{abstract}

Keywords: trolleybus transport, traction supply systems, transmision losses, energy savings, electrical measurement

\section{INTRODUCTION}

The development of zero-emission public transport is one of the elements of the EU's horizontal policy. Municipal transport is currently responsible for $40 \%$ of $\mathrm{CO}_{2}$ emissions of the entire road transport in Europe. The transport sector is responsible for $30 \%$ of total energy consumption and $27 \%$ of greenhouse gas emissions. Greenhouse gas emissions must be reduced by $60 \%$ by 2050 [Falvoa et al. 2011; Donno et al. 2012]. What is more, the instability of liquid fuel prices has an extremely negative impact on the economy. Therefore, using more alternative energy sources in public transport becomes necessary. [Kuhne. 2010; Gunselmann. 2005]. Electricity is an alternative to liquid fuels. Today, we may notice an increase in the popularity of cars and electric buses powered by automotive batteries; however, the most effective way of providing electricity to vehicles is still an overhead line or catenary.

The development of electric means of transport is actively supported by the European authorities, as evidenced e.g. by funding initiatives popularising ecological municipal transport systems from the Community budget. Examples of such projects are Trolley,Actuate,Dyn@mo and Osiris [Połom and Palmowski 2009; Połom and Bartłomiejczyk 2011] which focused on the development of energy-saving technologies applied in them.

\section{ENERGY EFFICIENCY OF ELECTRIC MUNICIPAL TRANSPORT}

Each of the steps of generation and conversion of electricity is related to the occurrence of losses. These arise in the production of energy, at transmission to the public power grid, during the processing stage at the traction substations supplying the overhead line and in the overhead line. Moreover, the electric vehicle drives have limited energy efficiency.

The efficiency of electricity generation and public HV transmission systems is the subject of many scientific publications in the field of power systems. [Scarpellini et al. 2013; Sweet- 
ing et al. 2011; Jarzyna 2011; Zielinski et al. 2015]. Energy efficiency of the drive unit is also the subject of numerous studies and considerable research. [Judek and Skibicki 2019; Jarzębowicz 2011, 2014; Dolecek et al. 2012; Hrbac et al. 2014; Kolano 2012, 2015]. The element that is least frequently analysed in scientific research related to energy efficiency is the overhead line and its supply system. The overhead line generates losses during supply of electricity from the traction substation to vehicles. However, this fact is underestimated by experts in the field of supply of municipal overhead lines. This results in designing and constructing power supply systems for tram and trolleybus lines without taking into account the need to minimise transmission losses in the line. On the basis of the operational experience, transmission losses in the overhead line can reach values as high as $30 \%$, and a badly formed power supply system can significantly reduce the use of recovered energy. Issues such as the spatial structure of the power supply system, division of the overhead line into sections and the manner of supplying the sections are crucial in view of minimising energy consumption by public transport [Hamacek et al. 2014].

The problem of transmission losses in catenary power supply systems of public transport has been marginalised for many years. The main criterion for the power circuit design was to obtain the highest reliability. This approach was required by a high failure rate of the rolling stock and catenary. Furthermore, the classic, contactor rheostatic drive systems were characterised by high losses at the level of up to $40 \%$. In relation to energy losses occurring in vehicles, energy losses in the catenary were much smaller, and thus thought to be unimportant [Korga et al. 2015]. The energy efficiency of power electronic drive systems of trams and trolleybuses is now close to the maximum. Therefore, it is necessary to look for ways of improving the energy efficiency of urban traction in other areas, including reducing transmission losses.

The accuracy and frequency of electricity consumption measurement in traction power systems is also an important issue. Many transport companies introduced billing of trolleybus and tram drivers for the level of electricity consumption. Moreover, in the future we should expect the opening of tram and trolleybus infrastructure in different cities by private carriers. This will put even more emphasis on issues related to the billing of energy consumption. Therefore, measurement and analysis of losses arising from the transmission of electricity for traction vehicles is becoming an increasingly important issue.

\section{MEASUREMENT OF THE TRANSMISSION LOSSES}

Trams and trolleybuses are supplied from the overhead line. Energy is drawn from the public HV AC grid and is converted to DC in traction substations. After transformation and rectification, the energy from traction substations is supplied into power supply points of overhead lines using power cables - the so-called feeders. The overhead line is divided into traction power supply sections.

The spatial structure of the overhead line power supply system affects the energy transmission losses in the overhead line. Transmission losses are dependent on the resistance of the conductor, or power cables and the overhead line. This, in turn, depends on their length. The increase in the distance between substations and lengthening the power cables enhances the transmission losses. A significant source of energy dissipation in the supply systems are losses in long power cables, the length of which can be up to several kilometres [Hamacek et al. 2014].

Most scientific works publish the values of transmission losses based only on theoretical simulations. [Hamacek et al. 2014]. The measurement of transmission losses in tram or trolleybus supply systems is difficult due to the complicated structure of the city transport network. These loses can be estimated on the basis of the energy balance of the supply system as a difference between the energy taken by traction substation and the energy consumed by vehicles. Unfortunately, in many cities not all vehicles are equipment with an energy measuring system and there is no precise information about the energy consumption of the vehicles. Moreover, this method does not allow to eliminate the energy consumed by substations and by other non-vehicle receivers connected to traction catenary (e.g. ticket machines or steering and heating of rail switches).

Reference [EE\&C BUT 2014] presents a method of determining transmission losses based on the measurement of the vehicle current, which assumed constant equivalent values of resistance between substation and vehicle in every place of 
the traction network. The losses are calculated as the product of this resistance and the square of vehicle current. However, the topology and structure of the supply system is very complicated and the resistance of the supply system is different in each place of the network and cannot be replaced by one constant value. Moreover, the dependence between the value of the current and the transmission losses is not linear, giving the correct result of the calculation only when the power section is located only on one vehicle. Consequently, the results given by the authors at the level of $2.5 \%$ seem to be too low and significantly different from the values given by other sources [Sweeting et al. 2011].

The authors of the present paper propose the method based on measuring of the voltage and current of the vehicles, which does not require the knowledge of the supply system resistance. Additionally, there is no need to carry out measurements in every vehicle.

Trolleybus current consumption of value $I_{v e h}$ increases the substation load current by the same amount $I_{v e h}$. Likewise, the power consumption of the trolleybus defined as:

$$
P_{v e h}=U_{v e h} \cdot I_{v e h}
$$

where: $U_{\text {veh }}$ - supply voltage of vehicle on catenary, increases the loading of the substation by value

$$
\Delta P_{T S}=U_{T S} \cdot I_{v e h}
$$

where $U_{T S}-$ output voltage of substation. Transmission losses $P_{\text {losses }}$ in the supply system during provision of power to the particular traction vehicle can be defined as:

$$
P_{\text {loss }}=\Delta P_{T S}-P_{\text {veh }}
$$

This formula can be modified into the following form:

$$
P_{l o s s}=I_{v e h} \cdot\left(U_{T S}-U_{v e h}\right)
$$

The relative value $e$ sof the transmission losses in time period from $t_{1}$ to $t_{2}$, based on (4), may be defined as:

$$
e=U_{T S} \cdot \frac{\int_{t_{1}}^{t_{2}} I_{v e h}(t) d t}{\int_{t_{1}}^{t_{2}} I_{v e h}(t) \cdot U_{v e h}(t) d t}-1
$$

What is important is that all relations are linear and will be valid for any number of vehicles.
For the purposes of the analysis, the values $I_{v e h}$ and $U_{v e h}$ are based on measurements of the energy consumption in trolleybuses, while the value $U_{T S}$ on measurements conducted in traction substations. The expected value of the voltage of busbar in the DC switchgear was assumed as the value of substation voltage $U_{T S}$. Table 1 shows the voltage $U_{T S}$ for each substation supplying the Gdynia trolleybus network, obtained in additional measurements.

\section{MEASUREMENT ANALYSIS OF THE CONDITION OF GDYNIA TROLLEYBUS NETWORK POWER SUPPLY SYSTEM}

The Gdynia trolleybus network has the length of $50 \mathrm{~km}$ and is powered by ten traction substations. The Trolleybus Transport Enterprise currently operates 85 trolleybuses. The supply system consists of 10 traction substations (TS1TS10, Table 1), each substation supplying from 1 to 6 supply feeder (Table 2).

The measurements were conducted on traction substations and in trolleybuses. To that effect, an on-board system of registration of the consumed energy was used along with the record GPS position over time, provided in units operating in Gdynia. This allows the determination of precise energy consumption in each supply section. During the measurements in vehicles, the values of the supply voltage and current taken from the supply system were measured.

Table 2 presents the results of the measurement analysis: transmission losses divided into losses in the various power supply sections, the areas of supply of traction substations and losses in the entire supply system. Figure 2 presents the map of transmission losses divided into individual supply stations.

Table 1. The voltage $U_{T S}$ of substations.

\begin{tabular}{|c|c|c|}
\hline TS No. & TS name & $U_{T S}$ \\
\hline 1 & Północna & $685 \mathrm{~V}$ \\
\hline 2 & Grabówek & $675 \mathrm{~V}$ \\
\hline 3 & Dworzec & $690 \mathrm{~V}$ \\
\hline 4 & Wendy & $685 \mathrm{~V}$ \\
\hline 5 & Kielecka & $684 \mathrm{~V}$ \\
\hline 6 & Redłowo & $680 \mathrm{~V}$ \\
\hline 7 & Sopot I & $690 \mathrm{~V}$ \\
\hline 8 & Sopot II & $704 \mathrm{~V}$ \\
\hline 9 & Wielkopolska & $690 \mathrm{~V}$ \\
\hline 10 & Chwaszczyńska & $690 \mathrm{~V}$ \\
\hline
\end{tabular}


Table 2. Relative values for transmission losses in different parts of the supply system

\begin{tabular}{|c|c|c|c|c|c|}
\hline TS & Setion No. & Section name & \multicolumn{3}{|c|}{$\begin{array}{c}\text { Transmission } \\
\text { losses }(\%)\end{array}$} \\
\hline \multirow{6}{*}{1} & $1 / 1$ & Cisowa & 4.9 & \multirow{6}{*}{9.1} & \\
\hline & $1 / 2$ & Kcyńska & 9.8 & & \\
\hline & $1 / 3$ & Poczta & 3.4 & & \\
\hline & $1 / 4$ & Gazownia & 9.1 & & \\
\hline & $1 / 5$ & Wiejska & 7.8 & & \\
\hline & $1 / 6$ & Pustki & 14.0 & & \\
\hline \multirow{3}{*}{2} & $2 / 1$ & Leszczynki & 6.0 & \multirow{3}{*}{8.9} & \\
\hline & $2 / 2$ & Grabówek & 5.0 & & \\
\hline & $2 / 3$ & Mleczarnia & 15.3 & & \\
\hline \multirow{3}{*}{3} & $3 / 1$ & Stocznia & 8.2 & \multirow{3}{*}{9.3} & \\
\hline & $3 / 2$ & $\begin{array}{l}\text { Dworzec } \\
\text { towarowy }\end{array}$ & 13.6 & & \\
\hline & $3 / 3$ & Plac Konstytucji & 2.8 & & \\
\hline \multirow{3}{*}{4} & $4 / 1$ & Plac Kaszubski & 5.7 & \multirow{3}{*}{7.0} & \\
\hline & $4 / 2$ & Świętojańska & 9.5 & & \\
\hline & $4 / 3$ & 10 lutego & 5.5 & & 8.5 \\
\hline \multirow{3}{*}{5} & $5 / 1$ & Warszawska & 8.7 & \multirow{3}{*}{6.0} & \\
\hline & $5 / 2$ & Węzeł & 2.5 & & \\
\hline & $5 / 3$ & Wzgórze & 4.8 & & \\
\hline \multirow{3}{*}{6} & $6 / 1$ & Redłowo & 7.7 & \multirow{3}{*}{9.1} & \\
\hline & $6 / 2$ & Kack & 11.7 & & \\
\hline & $6 / 3$ & Wielkopolska Klif & 7.8 & & \\
\hline \multirow{2}{*}{7} & $7 / 1$ & Kolibki & 5.7 & \multirow{2}{*}{8.0} & \\
\hline & $7 / 2$ & Sopot & 9.5 & & \\
\hline 8 & $8 / 1$ & Sopot II & 4.1 & 4.1 & \\
\hline 9 & $9 / 1$ & Wielkopolska & 7.2 & 7.2 & \\
\hline \multirow{5}{*}{10} & $10 / 1$ & Źródło Marii & 10.9 & \multirow{5}{*}{9.2} & \\
\hline & $10 / 2$ & Nowowiczlińska & 8.4 & & \\
\hline & $10 / 3$ & Miętowa & 6.1 & & \\
\hline & $10 / 4$ & Rdestowa & 7.2 & & \\
\hline & $10 / 5$ & Chwaszczyńska & 9.5 & & \\
\hline
\end{tabular}

Figure 1 presents the dependence between transmission losses and the average resistance $R_{S S}$ of cables and catenary of the supply sector defined as:

$$
R_{S S}=\frac{R_{M A X}-R_{M I N}}{2}
$$

where: $R_{\max } R_{\min }$ - maximum and minimum value of resistance between substation and vehicle (supply point and the end of the supply section).

Most of the points corresponding to the values of losses are located along a straight line, which reflects a linear relationship between the resistance of the conductor and transmission losses. Distance from the trend line illustrates the effect of the load on transmission losses. Points corresponding to sections with the trend line: visible is the example of the sections with the biggest traffic $2 / 3$ and $3 / 2$ and the least loaded section $10 / 3$.

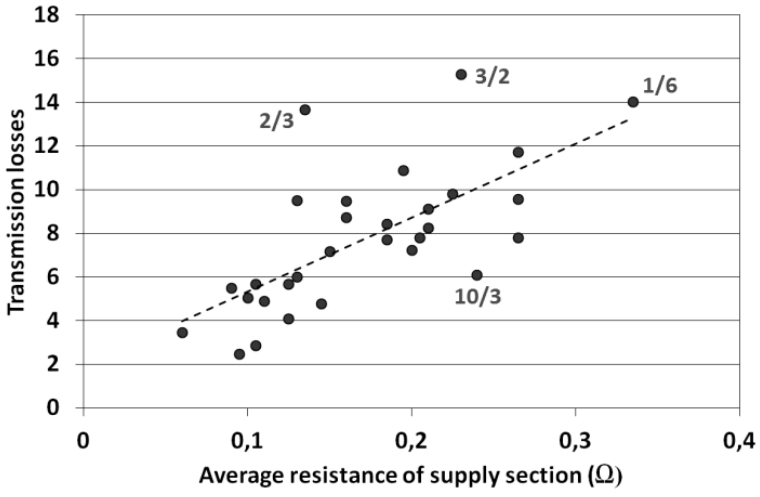

Fig. 1. The dependence between transmission losses and the average resistance of the catenary and supply cables $R_{S S}$ The points presenting the characteristic sections are marked

\section{ASSESSMENT OF THE CURRENT POWER SUPPLY SYSTEM}

Modernisation of the power supply system of the trolleybus network in Gdynia, conducted in the years 2009-2012, significantly improved the conditions of supplying the trolleybus transport. This is reflected in the energy efficiency of the power system. Average transmission losses in feeders and the overhead line amount to $8.5 \%$, which, in the case of a trolleybus system, can be considered a very good result. Losses in the electrical overhead line are generally assumed at the level of 10\%. [Jarzyna 2011; Zielinski et al. 2015]. This value is exceeded in Gdynia only in the case of several supply sections. On the basis of the conducted measurement tests in the existing supply system, the following issues and areas for improvement may be distinguished:

1) High energy transmission losses in power supply sections No. $2 / 3$ and $3 / 2(15.3 \%$ and 13.6\%). Transmission losses caused by the flow of electric current through a conductor are directly proportional to the resistance and the square of the current. Sections No. $2 / 3$ and $3 / 2$ are the parts of the network with very high traffic intensity. Consequently, the load current of those sections is significant, which results in significant transmission losses (Figures 1,2).

2) High energy transmission losses in power supply section No. 1/6 (14\%). This results from a significant length of the section of $2.5 \mathrm{~km}$. This is an effect of the significant resistance causing visible energy transmission losses. 


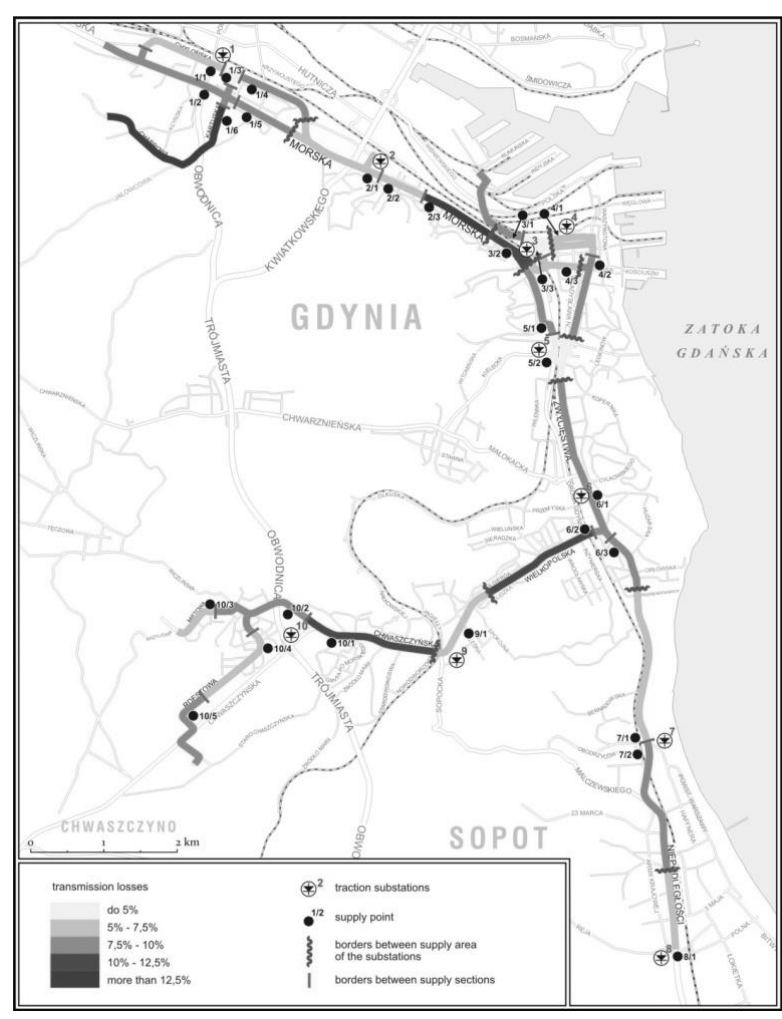

Fig. 2. Map of transmission losses in supply system in Gdynia (Author: Maciej Bejster)

\section{PECULIARITY OF THE LUBLIN TROLLEYBUS NETWORK POWER SUPPLY SYSTEM}

Lublin has the largest trolleybus traction network in Poland, which is currently supplying 130 trolleybuses. The structure of the network is far more complex than that presented for Gdynia. The cause of the complexity of the network is its sheer size and configuration of the terrain on which the city of Lublin is located, as well as various configurations of sections of the network related to its historical development.

The original catenary in Lublin was a centralised network, the characteristic feature of which was one DC supply station equipped with power rectifiers, with cable power lines supplied its individual fragments. The biggest drawback of such a system is high transmission losses associated with significant distances of certain parts of the catenary from the main DC power supply. However, the positive aspect of the extent of such a network was almost complete utilisation of trolleybus braking energy. The combination of different sections of the trolleybus traction through a common rail in the main DC power supply station meant that a large number of trolleybuses were at the same time connected to a common power supply. It gave a very good chance that a large dose of trolleybus braking energy would be consumed by other vehicles at the same time connected to the line. In such a structure it is extremely difficult to determine the effect of a single trolleybus on transmission losses in traction cables because there are interactions between the different moving trolleybuses, manifested by frequent fluctuations in DC voltage.

The Lublin traction network is continuously expanded and modernised. Along with the spread of the city, its traction network is expanded, which in the last two years extended the total length of the traction by almost $50 \%$.

The new sections are much shorter and built as autonomous, i.e. with their own rectifiers localised right next to them. This solution reduces transmission losses in the DC line, but exposes the network to greater voltage fluctuations in the case of simultaneous appearance of several trolleybuses at a given stretch of the line. On the other hand, it does not guarantee that the energy recuperation during the braking of a trolleybus will be fully utilised. There is a small probability that at any given moment another trolleybus will need such a high dose of energy to start or accelerate. As a result, that energy is dissipated in the braking resistor of a trolleybus.

An important modification in the new sections of the catenary and the modernised older parts of the system are compensatory connections involving combining at certain intervals the overhead line for the two directions of travel. This allows to sometimes reduce the effective resistance - and therefore also the transmission losses - in half.

In such a diverse and complex system, and a large number of powered trolleybuses it is more difficult to determine the contribution of each electric vehicle to transmission losses, especially that trolleybus traction in Lublin is based on a variety of technological solutions, not all of which are equipped with measurement and recording systems with a GPS.

\section{METHOD FOR DETERMINING COMPREHENSIVE LOSSES IN A POWER SYSTEM AND A CATENARY}

When trolleybuses move between the different sections, and registration systems installed in the vehicles are not equipped with GPSs, it is 


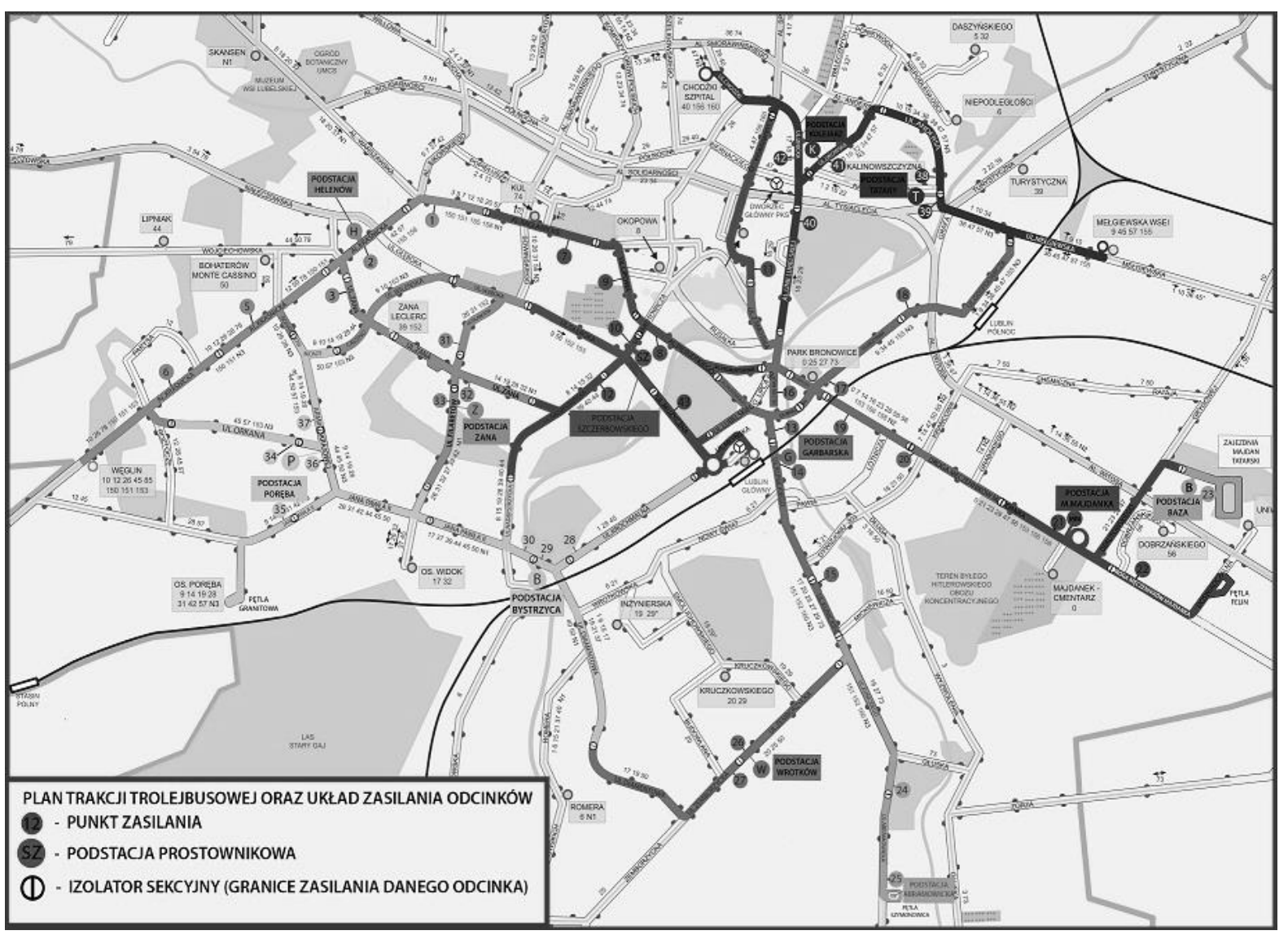

Fig. 3. Map of the trolleybus traction system in Lublin (MPK Lublin)

not possible to unambiguously assign the power charged by them, and thus the generated transmission losses, to specific power substations. In such case, it is only possible to determine the losses for the entire energy system based on aggregated energy intakes recorded on all trolleybuses and reference this value to the total energy supplied to the traction by substations supplying all the sections of the traction.

In order to calculate the total transmission losses for a given period of time, one must first determine the total amount of energy collected for traction purposes $E_{T}$. It is the sum of the differences in the energy taken from the $E_{P_{n}}$ grid and the own-needs energy $E_{W n}$ of $n$ individual substations.

$$
E_{T}=\sum_{i=1}^{n}\left(E_{P n}-E_{W n}\right)
$$

Energy consumed by trolleybuses $E_{t}$ in the period studied can be defined as the difference in energy taken $E_{+t m}$ and energy returned (during braking) to the traction network $E_{+t m}$ by $m$ trolleybuses.

$$
E_{t}=\sum_{i=1}^{m}\left(E_{+t m}-E_{-t m}\right)
$$

Energy transmission losses $E_{s t}$ expressed in percentage are as follows:

$$
E_{s t}=\frac{E_{T}-E_{t}}{E_{T}} 100 \%
$$

The analysis conducted by the MPK (City Transport Enterprise) in Lublin during the months of July-August 2012 showed that the existing centralised system during the summer months, i.e. while the current consumption by the trolleybuses is relatively low, electricity transmission losses amounted to about $11 \%$.

Another analysis, carried out in December 2015 , concerned an already expanded, half-decentralised system. It took place during a winter month, i.e. in the period when the current consumption is highest during the calendar year. Energy consumption by the overall system of overhead line and substations amounted at that time $E_{T}=937080 \mathrm{kWh}$. Accordingly, the power requirements of the three substations employed in the central system amounted to $7.14 \mathrm{kWh}$ each, while of the eight substations operating in a decentralised system - to $3.6 \mathrm{kWh}$ each. From the measurement systems installed in trolleybuses it 
Table 3. The values of energy used at the various substations in December 2016 and the total energy consumed by trolleybuses.

\begin{tabular}{|c|l|c|c|c|}
\hline $\begin{array}{c}\text { TS } \\
\text { No. }\end{array}$ & \multicolumn{1}{|c|}{ TS section } & $\begin{array}{c}E_{P_{n}} \\
(\mathrm{kWh} / \mathrm{month})\end{array}$ & $E_{W n}(\mathrm{kWh} / \mathrm{month})$ & $\begin{array}{c}E_{T n} \\
(\mathrm{kWh} / \mathrm{month})\end{array}$ \\
\hline 1 & SCZERBOWSKIEGO & $17,4031.80$ & $5,312.16$ & $168,719.64$ \\
\hline 2 & GARBARSKA & $19,5640.20$ & $5,312.16$ & $190,328.04$ \\
\hline 3 & HELENÓW & $16,6425.30$ & $5,312.16$ & $161,113.14$ \\
\hline 4 & M. MAJDANKA & $74,415.78$ & $2,678.40$ & $71,737.38$ \\
\hline 5 & ABRAMOWICKA & $73,638.00$ & $2,678.40$ & $70,959.60$ \\
\hline 6 & KOLEJARZ & $40,684.50$ & $2,678.40$ & $38,006.10$ \\
\hline 7 & TATARY & $23,495.94$ & $2,678.40$ & $20,817.54$ \\
\hline 8 & WROTKÓW & $38,072.70$ & $2,678.40$ & $35,394.30$ \\
\hline 9 & BAZA & $28,782.36$ & $2,678.40$ & $62,103.96$ \\
\hline 10 & PORĘBA & $64,882.62$ & $2,678.40$ & $54,332.46$ \\
\hline 11 & ZANA & $57,010.86$ & $2,678.40$ & $899,716.38$ \\
\hline Total energy (kWh/month) & $937,080.06$ & $37,363.68$ & \\
\hline $\begin{array}{l}\text { Energy consumed by } \\
\text { vehicles (kWh/month) }\end{array}$ & & $813,836.00$ & \\
\hline Losses (\%) & & 9.55 & \\
\hline
\end{tabular}

can be seen that they consumed $813836 \mathrm{kWh}$ of power. Analyses show that in the catenary system currently existing in Lublin, the energy of transmission and transformation losses in electrical substations is $9.55 \%$ of the energy collected from the supply substations for the purposes of traction. Thus, there is a noticeable impact of the decentralisation of the trolleybus power supply system on the reduction of the transmission losses within that system.

\section{CONCLUSIONS}

The method presented allows measurement of transmission losses in traction supply system, which requires the registration of the vehicle current, vehicle supply voltage, substation voltage and the GPS localisation of the vehicle. These values can be easily measured. The efficient energy in a particular place of the supply system can be set. The method can be used for diagnostic purposes of supply systems and energy efficiency assessment as part of the energetic audit of the public transport system.

The conducted measurements and simulations indicate a strong relationship between the traffic conditions, spatial structure of the supply system and the transmission losses.

Generally, transmission losses in the supply system are less than $10 \%$, but it should be underlined that in unfavourable situations they can reach high values, even greater than $15 \%$. This has a significant impact on the total energy consumption. It confirms the desirability of performing detailed measurements of transmission losses, which can help in finding the weak points in the supply system.

While the intensity of traffic is dependent on external factors and energy management services have a limited impact on it, greater efficiency of the supply system can be achieved by reducing the resistance of the catenary and power cables. The easiest way to reduce the resistance is reconfiguration of the supply system e.g. by the introduction of a two-sided power supply system [Hamacek et al. 2014] or compensatory connections between both directions of traffic. Decentralisation of the system, which helps to reduce transmission losses in the DC circuit by shortening the length of the cables supplying the traction, is also very important.

The transmission losses in the power distribution network are a quadratic function of the current. Therefore, they can be significantly reduced by limiting the power peaks caused by the simultaneous acceleration of different vehicles in the network and optimisation of timetables [González-Gil et al. 2014, 2015].

In summary, the first step to reduce transmission losses should be the reconfiguration of the supply system. Such action allows to obtain the desired effects with minimum financial efforts. 


\section{REFERENCES}

1. Dolecek R., Cerny O., Novak J., Bartłomiejczyk M. 2012. Interference in Power system for traction drive with PMSM. Przegląd Elektrotechniczny, 88(9a), 204-207.

2. Donno M., Ferrari A., Scarpelli A., Perlo P., Bocca A. 2012. Mechatronic System for Energy Efficiency in Bus Transport. IEEE Conference Publications, 2012, 342-343.

3. EE\&C BUT 2014. Possibilities of energy demand reduction in trolleybus transportation - Technical analysis. Faculty of Electrical Engineering and Communication Brno University of Technology, Department of Power Electrical and Electronic Engineering, Brno 2014.

4. Falvoa M.C., Lamedica R., Bartoni R., Maranzano G. 2011. Energy management in metro-transit systems: an innovative proposal toward an integrated and sustainable urban mobility system including plug-in electric vehicles. Electric Power Systems Research, 81, 2127-2138.

5. González-Gil A., Palacin R., Batty P. 2015. Optimal energy management of urban rail systems: Key performance indicators. Energy Conversion and Management, 90, 282-291.

6. González-Gil A., Palacin R., Batty P., Powell J.P. 2014. A systems approach to reduce urban rail energy consumption. Energy Conversion and Management, 80, 509-524.

7. Gunselmann W. 2005. Technologies for Increased Energy Efficiency in Railway Systems. Conference EPE 2005 Dresden, 1-10.

8. Hamacek S., Bartłomiejczyk M., Hrbac R., Misak
S., Styskala V. 2014. Energy recovery effectiveness in trolleybus transport. Electric Power Systems Research, 112, 1-11.

9. Jarzębowicz L. 2011. Sensorless IPMSM drive with rotor position estimator based on analysis of phase current derivatives. IEEE International Symposium on Industrial Electronics (ISIE 2011), 733-738.

10. Jarzębowicz L. 2014. Indirect Measurement of Motor Current Derivatives in PMSM Sensorless Drives. Elektronika i Elektrotechnika, 20(7).

11. Jarzyna W. 2011. Terms of the turbine and generator choice of wind power stations. Rynek Energii, 4, 102-106.

12. Judek S., Skibicki J. 2019. Wyznaczanie parametrów elektrycznych trakcyjnego układu zasilania dla złożonych warunków ruchu przy wykorzystaniu programu pSpice. Przegląd Elektrotechniczny, $12,270-273$.

13. Kolano K. 2012. Lift car doors drive system with hi-efficient BLDC drive. Przegląd Elektrotechniczny, 88(11B), 348-349.

14. Kolano K. 2015. Calculation of the brushless dc motor shaft speed with allowances for incorrect alignment of sensors. Metrology and Measurement Systems, 22(3), 393-402.

15. Korga S., Szulżyk-Cieplak J., Gnapowski S. 2015. Ocena zmian chropowatości powierzchni modelu 3D przy wykorzystaniu warunków brzegowych w analizie MES. Szkoła Inżynierii Materiałowej, 43, 277-281.

16. Kuhne R. 2010. Electric buses, an energy efficient urban transportation means. Energy, 35, 4510-4513. 